\title{
PENGARUH FAKTOR BUDAYA, SOSIAL, PERSONAL, DAN PSIKOLOGIS TERHADAP KEPUTUSAN PEMBELIAN PRODUK OLAHAN IKAN LAUT
}

\author{
Siti Maroah ${ }^{1}$, ${ }^{*}$ Maria Ulfa ${ }^{2}$ \\ 1,2 Program Studi Manajemen, Fakultas Ekonomi dan Bisnis, Universitas Muhammadiyah Surabaya \\ ${ }^{*}$ mariaulfa890@gmail.com
}

\section{Informasi Artikel \\ Draft awal: September 2021 \\ Revisi : September 2021 \\ Diterima : September 2021 \\ Available online: September 2021}

Keywords: Cultural, Social, Personal, Psychological, Purchase Decision

Tipe Artikel : Research paper

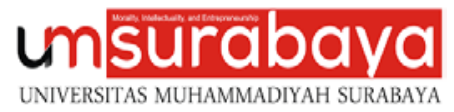

Diterbitkan oleh Universitas Muhammadiyah Surabaya

\begin{abstract}
This study aims to determine the influence of cultural, social, personal, and psychological factors on the purchase decision of marine fish processed products at Fish Centerof Bulak Kenjeran, Surabaya. The population of this study are consumers of marine fish processed products in Fish Center of Bulak, while the sampling technique used in this study is convenience sampling. The total sample is 100 people. The instrument of this study is a questionnaire that has previously been tested and has met the validity and reliability requirements. The data are analyzed using multiple regression analysis.
\end{abstract}

This study is processed using the IBM SPSS Statistics 23 program. The results show that cultural factors (X1), social factors (X2), personal factors (X3), and psychological factors (X4) simultaneously has impact on purchasing decisions (Y) with the Fcount 8,669>Ftable 2,47. Based on the results of the regression coefficient value with the test carried out on the four independent variables, it shows that the psychological factor variable (X4) has a dominant effect on purchasing decisions (Y).

Penelitian ini bertujuan untuk mengetahui pengaruh faktor budaya, sosial, personal, dan psikologis terhadap keputusan pembelian produk olahan ikan laut di Sentra Ikan Bulak Kenjeran Surabaya. Populasi penelitian ini adalah konsumen produk olahan ikan laut Sentra Ikan Bulak sedangkan teknik sampel yang digunakan dalam penelitian ini adalah convenience sampling dengan jumlah sampel sebanyak 100 orang. Instrumen yang digunakan menggunakan kuesioner yang sebelumnya telah diujicobakan dan telah memenuhi syarat validitas dan realibilitas sedangkan untuk analisis data menggunakan analisis regresi berganda.

Penelitian ini diolah menggunakan program IBM SPSS Statistics 23. Hasil penelitian menunjukkan bahwa variabel faktor budaya (X1), faktor sosial (X2), faktor personal (X3), faktor psikologis (X4) berpengaruh secara simultan terhadap keputusan pembelian (Y) dengan nilai Fhitung 8,669>Ftabel 2,47. Berdasarkan hasil dari nilai koefisien regresi dengan uji t yang dilakukan pada keempat variabel independen menunjukkan bahwa variabel faktor psikologis (X4) berpengaruh dominan terhadap keputusan pembelian (Y).

\section{PENDAHULUAN}

Produk perikanan dianggap sebagai sumber penting makanan nutrisi untuk manusia, diantara manfaat ikan ialah sebagai salah satu makanan yang mengandung varietas gizi. Selain itu ikan adalah makanan yang kaya protein yang benarbenar penting bagi pertumbuhan tubuh, sebagai sumber protein, lemak, vitamin dan mineral yang benar-benar baik (Djunaidah, 2017). Indonesia sendiri adalah salah satu negara dengan konsumsi ikan tertinggi di dunia. Jawa Timur termasuk diantara salah satu wilayah yang memiliki potensi dalam sektor perikanan, baik sektor perikanan tangkap maupun budidaya.

Kota Surabaya dengan kawasan sepanjang pantai Kenjeran adalah wilayah perarian dengan 
hasil laut melimpah dan merupakan pusat pelelangan ikan untuk memenuhi kebutuhan ikan segar maupun olahan ikan di Surabaya dan sekitarnya. Salah satu tempat pelelangan ikan di kota Surabaya adalah sentra olahan ikan laut (OIL) yang biasa disebut dengan nama Sentra Ikan Bulak (SIB) terletak di Sukolilo kelurahan Kedung Cowek Kecamatan Bulak Surabaya.

Hasil pengamatan yang dilakukan bahwa terdapat pemasalahan eksternal yang berupa kurang optimalnya penggunaan sarana pendukung pengolahan seperti tempat pengolahan ikan dan tempat pemasaran. Pedagang enggan untuk menempati Sentra Ikan Bulak (SIB) sebagai pusat pemasaran walaupun stan disediakan secara gratis, mereka lebih memilih berdagang di bahu jalan dan tetap melakukan pengolahan dihalaman rumah mereka sendiri. Hal ini disebabkan kurangnya pendekatan yang optimal dengan melibatkan pedagang dan masyarakat sekitar mengenai Sentra Ikan Bulak. Temuan observasi ini didukung oleh penelitian yang dilakukan oleh Asriningputri \& Handayeni, (2019) dalam penelitiannya mengemukakan bahwa kondisi beberapa bangunan yang tidak permanen, beberapa bangunan kondisinya kurang baik yang dapat dilihat dari kurangnya kebersihan maupun papan nama yang sudah tidak terbaca. Kondisi seperti ini tentu saja kurang mampu menarik pengunjung atau wisatawan.

Observasi peneliti di Sentra Ikan Bulak menemukan bahwa perilaku pembelian konsumen pada Sentra Ikan Bulak (SIB) saat ini lebih berorientasi pada suasana lingkungan tempat berbelanja yang berdekatan dengan kawasan wisata dan budaya masyarakat sekitar yang merupakan nelayan. Di satu sisi dengan perkembangan zaman yang berdampak langsung pada masyarakat juga mengalami perubahan pemilihan tempat untuk membeli kebutuhan sehari-hari yaitu terjadinya pergeseran gaya hidup dari tradisional menjadi modern, sehingga mempengaruhi keputusan pembelian konsumen yang berdampak pada penurunan minat beli di Sentra Ikan Bulak (SIB). Kondisi tersebut patut menjadi perhatian penting bagi pedagang dan pengelola Sentra Ikan Bulak agar dapat meningkatkan daya saing produk yang pada akhirnya mempengaruhi persepsi keputusan pembelian.

Banyak sekali faktor-faktor yang bisa mempengaruhi individu maupun kelompok dalam memutuskan menggunakan suatu produk. Hal ini disebabkan karena masyarakat Indonesia memiliki budaya, agama, dan suku yang sangat beragam. Peran dan fungsi perilaku konsumen sebagai penghubung antara tindakan dan faktor pendorong konsumen pada saat sebelum membeli, ketika membeli, ketika menggunakan, hingga ketika konsumen melakukan evaluasi terhadap produk dan jasa. Hal tersebut menunjukkan bahwa perilaku konsumen berperan dalam memahami tindakan yang dilakukan individu maupun kelompok yang berkaitan dengan proses pengambilan keputusan untuk memperoleh dan menggunakan suatu produk.

Keputusan pembelian merupakan suatu tindakan keputusan konsumen dalam membeli dan menggunakan suatu produk sesuai dengan kebutuhan dan kemampuannya (Suroto, 2013). Disisi lain perilaku pengambilan keputusan konsumen sangat mempengaruhi apakah konsumen membeli atau tidak produk yang ditawarkan.

Berdasarkan latar belakang diatas peneliti ingin mengungkap kembali lebih dalam faktorfaktor keputusan pembelian produk olahan perikanan. Hal ini dirasa perlu karena keputusan pembelian produk perikanan di pasar tradisional diprediksi memiliki faktor-faktor pembentuk yang berbeda dengan faktor-faktor keputusan pembelian lainnya. Sehingga penelitin ini memiliki tujuan untuk menguji Pengaruh faktorfaktor budaya, sosial, personal dan psikologis terhadap keputusan pembelian produk olahan ikan laut (OIL), studi pada konsumen Sentra Ikan Bulak Kenjeran Surabaya”.

\section{LANDASAN TEORI}

\section{Pemasaran}

The Cratered Institute of Marketing (CIM) memberi definisi pemasaran sebagai proses manajemen dalam mengidentifikasi, mengantisipasi, dan memuaskan pelanggan untuk mendapatkan keuntungan. The American Marketing Association (AMA) memberi definisi pemasaran sebagai serangkaian aktivitas dari institusi dan proses untuk menciptakan komunikasi, penyampaian, dan pertukaran penawaran yang memiliki nilai bagi pelanggan, klien, mitra bisnis, dan masyarakat secara luas (Kotler \& Keller, 2012). 


\section{Perilaku Konsumen}

Menurut Kotler \& Keller, (2012), perilaku konsumen adalah studi tentang bagaimana individu, kelompok, dan organisasi memilih, membeli, menggunakan, dan bagaimana barang, dan jasa, ide, atau pengalaman untuk memuasakan kebutuhan dan keinginan mereka.

\section{Perilaku Pembelian}

Menurut Kotler \& Keller, (2012) terdapat empat faktor utama yang mempengaruhi perilaku pembeli. Faktor tersebut berasal dari faktor kebudayaan dengan indicator budaya, sub budaya, kelas sosial. Faktor sosial yang dibagi menjadi indikator kelompok referensi, keluarga, peran dan status konsumen. Faktor pribadi dengan indikator usia dan tahap siklus hidup, pekerjaan, gaya hidup dan kepribadian konsumen. Faktor psikologi dengan indikator motivasi, persepsi, pembelajaran, dan sikap.

\section{Keputusan Pembelian}

Kotler \& Keller, (2012) menjelaskan keputusan pembelian adalah keputusan yang diambil konsumen untuk melakukan pembelian suatu produk melalui tahapan-tahapan yang dilalui konsumen sebelum melakukan pembelian yang meliputi: kebutuhan yang dirasakan, kegiatan sebelum membeli, perilaku waktu memakai, dan perasaan setelah membeli.

Adapun proses keputusan pembelian dijelaskan sebagai berikut Kotler \& Keller, (2012):
1. Pengenalan masalah
2. Pencarian Informasi
3. Evaluasi Alternatif
4. Keputusan Pembelian
5. Perilaku Purna Pembelian

\section{METODE PENELITIAN}

Penelitian ini menggunakan pendekatan kuantitatif. Populasi yang digunakan dalam penelitian ini adalah semua orang yang pernah berbelanja produk olahan ikan laut (OIL) di Sentra Ikan Bulak Kenjeran Surabaya. Jumlah populasi dalam penelitian tidak dapat teridentifikasi.

Teknik pengambilan sampel yang digunakan dalam penelitian ini adalah non probability sampling dengan jenis convenience sampling. Jenis sampel convenience sampling adalah jenis penentuan sampel dengan pertimbangan kemudahan. Seseorang diambil sebagai sampel karena kebetulan orang itu berada di tempat penelitian (Fatihudin, 2015). Ukuran sampel pada penelitian ini ditentukan dengan pedoman (Ferdinand, 2011) bahwa ukuran sampel tergantung pada jumlah indikator yang digunakan dalam seluruh variabel laten, jumlah sampel adalah jumlah indikator dikali 5. Penelitian ini menggunakan 20 indikator, sehingga dengan menggunakan estimasi berdasarkan jumlah indikator diperoleh ukuran sampel bekisar 100 orang. Jumlah sampel yang harus terpenuhi dalam penelitian ini sebanyak 100 orang responden..

\section{HASIL DAN PEMBAHASAN}

\section{Hasil}

\section{Karakteristk Responden}

Dari hasil data kuesioner penelitian ini dilakukan pada konsumen Sentra Ikan Bulak Surabaya dapat disimpulkan bahwa karakteristik responden sebagai berikut:

a. Jenis kelamin responden dengan jumlah terbanyak didominasi oleh perempuan dengan presentase sebesar $60 \%$.

b. Rata-rata responden berusia 31-40 tahun yang berkunjung dengan presentase sebesar $44 \%$.

c. Status pekerjaan responden Sentra Ikan Bulak didominasi sebagai karyawan dengan presentase $45 \%$ sebagai karyawan.

d. Tingkat pendapatan responden perbulan sebesar Rp 2.000.000-Rp 3.000.000 dengan presentase $28 \%$.

Produk yang sering dibeli dengan jumlah pilihan dari responden terbanyak membeli produk olahan ikan asap dengan presentase barang-barang yang dibawa oleh tamu ke kamarnya menggunakan trolley.

\section{Pengujian Instrumen}

\section{a. Uji Validitas}

Berdasarkan hasil validitas untuk menunjukkan bahwa keseluruhan item yang digunakan sebagai alat ukur variabel faktor budaya $\left(\mathrm{X}_{1}\right)$, faktor sosial $\left(\mathrm{X}_{2}\right)$, faktor personal $\left(\mathrm{X}_{3}\right)$, faktor psikologis $\left(\mathrm{X}_{4}\right)$ adalah valid.

\section{b. Uji Reliabilitas}

Berdasarkan hasil reliabilitas menunjukkan bahwa keseluruhan item yang digunakan sebagai alat ukur variabel faktor budaya $\left(X_{1}\right)$, faktor sosial $\left(X_{2}\right)$, faktor personal $\left(\mathrm{X}_{3}\right)$, faktor psikologis $\left(\mathrm{X}_{4}\right)$ adalah reliabel. 


\section{Pengujian Hipotesis}

a. Uji Normalitas

Tabel 1 Uji Normalitas

\begin{tabular}{llr}
\hline \multicolumn{2}{c}{ One-Sample Kolmogorov-Smirnov Test } \\
\hline & Mean & $\begin{array}{c}\text { Unstandardized } \\
\text { Residual }\end{array}$ \\
\hline $\mathrm{N}$ & 100 \\
Normal & Std. &, 0000000 \\
Parameters ${ }^{\mathrm{a}, \mathrm{b}}$ & Deviation & 2,44276714 \\
Most Extreme & Absolute &, 080 \\
Differences & Positive &, 040 \\
& Negative &,- 080 \\
Test Statistic &, 080 \\
Asymp. Sig. (2-tailed) &, $118^{\mathrm{c}}$ \\
\hline a. Test distribution is Normal. & \\
b. Calculated from data. & \\
c. Lilliefors Significance Correction.
\end{tabular}

Berdasarkan tabel 1 hasil uji normalitas diketahui variabel faktor budaya, sosial, personal, psikologis dan keputusan pembelian menghasilkan taraf signifikansi $>0,05$ sehingga dapat disimpulkan bahwa nilai residual berdistribusi normal.

\section{b. Uji Multikolinieritas}

Tabel 2 Mulitkoliniritas

\section{Coefficients $^{\mathrm{a}}$}

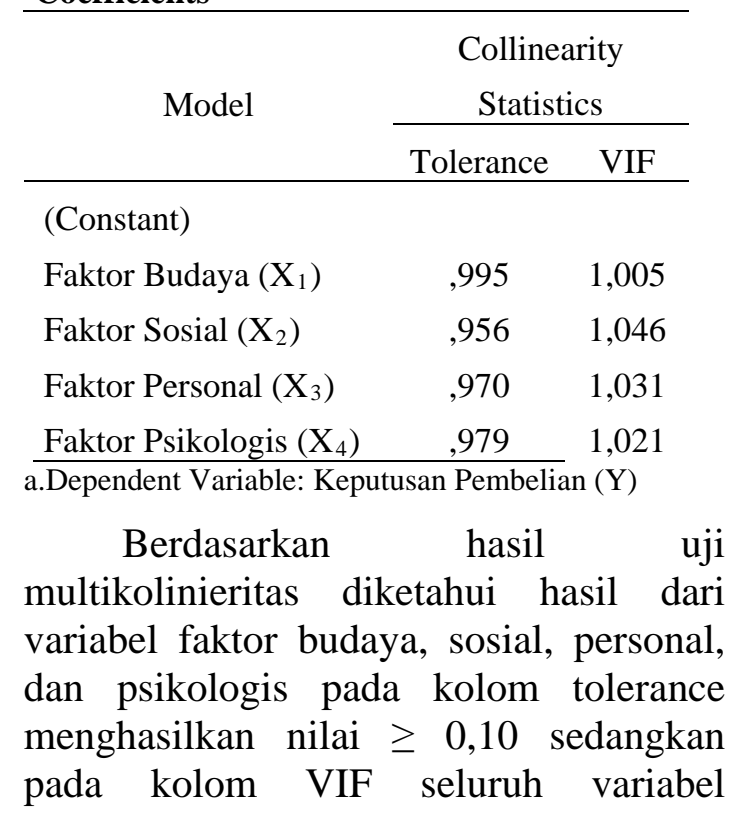

menghasilkan $\leq 10$ maka disimpulkan tidak terjadi masalah multikolinieritas.

c. Uji Heterokedastisitas

Tabel 3 Heterokedastisitas

\section{Coefficients $^{\mathbf{a}}$}

\begin{tabular}{lcc}
\hline \multicolumn{1}{c}{ Model } & $\mathrm{t}$ & Sig. \\
\hline (Constant) &, 446 &, 657 \\
Faktor Budaya $\left(\mathrm{X}_{1}\right)$ & 1,050 &, 296 \\
Faktor Sosial $\left(\mathrm{X}_{2}\right)$ &,- 228 &, 820 \\
Faktor Personal $\left(\mathrm{X}_{3}\right)$ & 1,383 &, 170 \\
Faktor Psikologis $\left(\mathrm{X}_{4}\right)$ & $-1,860$ &, 066 \\
\hline a. Dependent Variable: Abs_Res &
\end{tabular}

Berdasarkan pengolahan uji heterokedastisitas ditunjukan pada tabel 3 yang menggunakan uji Glejser bahwa variabel yang diuji tidak terjadi heteroskedastisitas dan signifikan dengan menghasilkan nilai masing-masing variabel bebas $>0,05$ sehingga dapat disimpulkan tidak terjadi masalah heterokedastisitas.

d. Uji Regresi Linier Berganda

\section{Coefficients $^{\mathrm{a}}$}

\begin{tabular}{|c|c|c|c|}
\hline \multirow{2}{*}{ Model } & \multicolumn{3}{|c|}{$\begin{array}{l}\text { Unstandardize Standardized } \\
\text { d Coefficients Coefficients }\end{array}$} \\
\hline & B & $\begin{array}{l}\text { Std. } \\
\text { Error }\end{array}$ & Beta \\
\hline (Constant) & ,470 & 4,618 & \\
\hline $\begin{array}{l}\text { Faktor Budaya } \\
\left(\mathrm{X}_{1}\right)\end{array}$ & ,212 & ,092 & ,203 \\
\hline Faktor Sosial $\left(\mathrm{X}_{2}\right)$ & 218 & 103 & 190 \\
\hline $\begin{array}{l}\text { Faktor Personal } \\
\left(\mathrm{X}_{3}\right)\end{array}$ & ,255 & 081 & ,282 \\
\hline $\begin{array}{l}\text { Faktor Psikologis } \\
\left(\mathrm{X}_{4}\right)\end{array}$ & ,329 & ,082 & ,356 \\
\hline
\end{tabular}

1. Konstanta (a) sebesar 0,470 artinya apabila variabel bebas faktor budaya, faktor sosial, faktor personal dan faktor psikologis adalah bernilai konstan, maka besarnya variabel terikat keputusan pembelian adalah sebesar 0,470.

2. Variabel faktor budaya memiliki nilai koefisien sebesar 0,212. Artinya jika variabel faktor budaya $\left(\mathrm{X}_{1}\right)$ meningkat 
sebesar $1 \%$ dengan asumsi variabel sosial $\left(\mathrm{X}_{2}\right)$, personal $\left(\mathrm{X}_{3}\right)$, dan psikologis $\left(\mathrm{X}_{4}\right)$ dan konstanta (a) adalah 0 (nol), maka keputusan pembelian akan meningkat sebesar 0,212 yang bernilai positif.

3. Variabel faktor sosial memiliki nilai koefisien sebesar 0,218. Artinya jika variabel faktor sosial $\left(\mathrm{X}_{2}\right)$ meningkat sebesar $1 \%$ dengan asumsi variabel budaya $\left(\mathrm{X}_{1}\right)$, personal $\left(\mathrm{X}_{3}\right)$, dan psikologis $\left(\mathrm{X}_{4}\right)$ dan konstanta (a) adalah 0 (nol), maka keputusan pembelian akan meningkat sebesar 0,218 yang bernilai positif

4. Variabel faktor personal memiliki nilai koefisien sebesar 0,255. Artinya jika variabel faktor personal $\left(\mathrm{X}_{3}\right)$ meningkat sebesar $1 \%$ dengan asumsi variabel budaya $\left(\mathrm{X}_{1}\right)$, sosial $\left(\mathrm{X}_{2}\right)$, dan psikologis $\left(\mathrm{X}_{4}\right)$ dan konstanta (a) adalah 0 (nol), maka keputusan pembelian akan meningkat sebesar 0,255 yang bernilai positif.

5. Variabel faktor psikologis memiliki nilai koefisien sebesar 0,329. Artinya jika variabel faktor psikologis $\left(\mathrm{X}_{4}\right)$ meningkat sebesar $1 \%$ dengan asumsi variabel budaya $\left(\mathrm{X}_{1}\right)$, sosial $\left(\mathrm{X}_{2}\right)$, dan personal $\left(\mathrm{X}_{3}\right)$ dan konstanta (a) adalah 0 (nol), maka keputusan pembelian akan meningkat sebesar 0,329 yang bernilai positif.

e. Uji Analisis Korelasi (R) Dan Determinasi $\left(\boldsymbol{R}^{\mathbf{2}}\right)$

Tabel 4. $R$ Square

Model Summary

\begin{tabular}{ccccc}
\hline $\begin{array}{c}\text { Mo } \\
\text { del }\end{array}$ & R & $\begin{array}{c}\mathrm{R} \\
\text { Square }\end{array}$ & $\begin{array}{c}\text { Adjusted R } \\
\text { Square }\end{array}$ & $\begin{array}{c}\text { Std. Error of } \\
\text { the Estimate }\end{array}$ \\
\hline 1 &, $517^{\mathrm{a}}$ &, 268 &, 237 & 2,494 \\
\hline
\end{tabular}

a. Predictors: (Constant), Faktor Psikologis (X4), Faktor Personal (X3), Faktor Budaya (X1), Faktor Sosial (X2)

Berdasarkan tabel 4 model summary tersebut diketahui nilai koefisien determinasi Adjusted $R$ Square $\left(\mathrm{R}^{2}\right)$ sebesar 0,237 atau $23,7 \%$ yang menunjukkan kontribusi dari variabel faktor budaya, faktor sosial, faktor personal, faktor psikologis terhadap keputusan pembelian produk olahan ikan laut di Sentra ikan Bulak Surabaya. 76,3\% dikontribusi oleh variabel lain yang tidak disebutkan dalam penelitian ini. Hasil koefisien korelasi berganda (R) ditunjukkan dengan nilai sebesar 0,517 atau 51,7\% yang mengindikasikan bahwa korelasi atau hubungan antara variabel faktor budaya, faktor sosial, faktor personal, dan psikologis memiliki pengaruh yang sedang terhadap variabel terikat atau keputusan pembelian.

f. Uji F (Simultan)

Tabel 5. Uji F

ANOVA $^{a}$

\begin{tabular}{lcrrcc}
\hline \multicolumn{1}{c}{ Model } & $\begin{array}{c}\text { Sum of } \\
\text { Squares }\end{array}$ & df & $\begin{array}{c}\text { Mean } \\
\text { Square }\end{array}$ & F & Sig. \\
\hline Regression & 215,816 & 4 & 53,954 & 8,677 &, $000^{\text {b }}$ \\
Residual & 590,744 & 95 & 6,218 & & \\
Total & 806,560 & 99 \\
\hline a. & Dependent Variable: Keputusan Pembelian (Y) \\
b. $\quad \begin{array}{l}\text { Predictors: (Constant), Faktor Psikologis (X4), Faktor } \\
\text { Personal (X3), Faktor Budaya (X1), Faktor Sosial } \\
\text { (X2) }\end{array}$
\end{tabular}

Uji $\mathrm{F}$ diperoleh dengan hasil perbandingan signifikasi $\mathrm{F}$ sig 0,000 $<0,05$. Nilai $F_{\text {tabel }}$ diperoleh sebesar 2,47. Nilai $\mathrm{F}_{\text {hitung }}$ 8,677 $>\mathrm{F}_{\text {tabel }}$ dengan nilai 2,47. Sehingga dapat disimpulkan bahwa antara faktor budaya $\left(\mathrm{X}_{1}\right)$, faktor sosial $\left(\mathrm{X}_{2}\right)$, faktor personal $\left(\mathrm{X}_{3}\right)$ dan faktor psikologis $\left(\mathrm{X}_{4}\right)$ berpengaruh secara simultan terhadap keputusan pembelian (Y).

c. Uji T (Parsial)

Tabel 6. Uji T (Parsial)

Coefficients $^{\mathrm{a}}$

\begin{tabular}{llcc}
\hline \multicolumn{1}{c}{ Model } & $\mathrm{t}$ & Sig. \\
\hline & (Constant) &, 102 &, 919 \\
& Faktor Budaya (X1) & 2,304 &, 023 \\
\multirow{2}{*}{1} & Faktor Sosial (X2) & 2,112 &, 037 \\
& Faktor Personal (X3) & 3,167 &, 002 \\
& Faktor Psikologis (X4) & 4,016 &, 000 \\
\hline
\end{tabular}

Berdasarkan hasil pengujian secara parsial diperoleh tingkat signifikan untuk variabel faktor budaya sebesar $0,23<0,05 \alpha=0,05$ (level 
of signifikan) dan nilai t hitung 2,304 > t tabel 1,985 , sehingga dapat disimpulkan bahwa $\mathrm{H}_{0}$ ditolak dan $\mathrm{H}_{1}$ diterima yang artinya variabel faktor budaya berpengaruh secara parsial terhadap keputusan pembelian. Sedangkan variabel sosial sebesar $0,037<\alpha=0,05$ (level of signifikan) dan nilai t hitung 2,112 > t tabel 1,985 sehingga dapat disimpulkan bahwa $\mathrm{H}_{0}$ ditolak dan $\mathrm{H}_{2}$ diterima yang artinya variabel faktor sosial berpengruh secara parsial terhadap keputusan pembelian. Sedangkan variabel personal sebesar $0,002<\alpha=0,05$ (level of signifikan) dan nilai $\mathrm{t}$ hitung 3,167 $>\mathrm{t}$ tabel 1,985 sehingga dapat disimpulkan bahwa $\mathrm{H}_{0}$ ditolak dan $\mathrm{H}_{3}$ diterima yang artinya

\section{Pembahasan}

Berdasarkan data hasil penelitian maka pembahasan mengenai hasil penelitian dapat dijelaskan sebagai berikut:

Pengaruh faktor budaya terhadap keputusan pembelian produk olahan ikan laut (studi pada konsumen Sentra Ikan Bulak Kenjeran Suabaya)

Berdasarkan hasil olah data yang telah dilakukan dalam penelitian ini, uji $\mathrm{t}$ (parsial) menunjukan bahwa nilai signifikan untuk pengaruh X1 terhadap Y adalah 0,023 $<\mathrm{a}=0,05$ dan nilai thitung $>$ ttabel dengan nilai 2,304 > 1,985 maka dapat disimpulkan bahwa H0 ditolak dan H1 diterima dan memiliki pengaruh signifikan, yang berarti faktor budaya mempunyai pengaruh positif dan signifikan terhadap keputusan pembelian produk olahan ikan laut pada konsumen Sentra Ikan Bulak Kenjeran Surabaya).

Variabel faktor budaya indikator terdiri dari: budaya konsumsi, sub budaya yang dibagi berdasarkan wilayah geografis konsumen, dan social experience atau pengalaman sosial konsumen. Berikut merupakan pembahasan dari masing-masing indikator. Budaya konsumsi konsumen yang datang ke Sentra Ikan Bulak mempunyai kebiasaan dalam melakukan kunjungan lebih dari satu kali kunjungan.

Kebiasaan konsumen dalam melakukan kunjungan paling sering dilakukan pada hari weekend

Sub budaya berdasarkan wilayah geografis konsumen yang datang ke Sentra Ikan Bulak sebagian besar konsumen yang sedang berkunjung di pantai Kenjeran atau di taman SuroboyoLetak Sentra Ikan Bulak yang strategis berada didepan tempat wisata dan di wilayah pemukiman pesisir pantai membuat mudah dijangkau oleh masyarakat baik ketika sedang berkunjung di pantai Kenjeran.

Self experience pengalaman sosial konsumen yang datang di Sentra Ikan Bulak sebagian besar adalah konsumen yang sudah mempercayai dan sudah pernah membeli produk olahan ikan laut di Sentra Ikan Bulak dan mereka memutuskan membeli dikarenakan kualitas produk olahan ikan laut di Sentra Ikan Bulak yang segar dan mengetahui secara langsung proses pengolahan produk yang dijual.

Menurut Kotler \& Keller, (2012) yang termasuk dalam budaya adalah pergeseran budaya serta nilai-nilai dalam keluarga. Sedangkan sub budaya adalah sekelompok orang dengan sistem nilai tersendiri berdasarkan pengalaman dan situasi kehidupan yang sama. Sub-budaya meliputi kebangsaan, agama, ras, dan wilayah geografis. Pembagian pengalaman sosial dalam masyarakat relatif permanen dan diorganisir oleh anggota yang menganut nilai-nilai, minat, dan perilaku yang serupa.Hasil penelitian ini bertentangan dengan penelitian yang telah dilakukan oleh Furaiji et al., (2012) yang menyatakan bahwa faktor budaya tidak memiliki pengaruh hubungan yang kuat dengan perilaku konsumen.

\section{Pengaruh faktor sosial terhadap keputusan pembelian pada produk olahan ikan laut (studi pada konsumen Sentra Ikan Bulak Kenjeran Surabaya)}

Berdasarkan olah data penelitian ini, uji t (parsial) menunjukan bahwa nilai signifikan pengaruh $\mathrm{X}_{2}$ terhadap $\mathrm{Y}$ adalah $0,037<\mathrm{a}=0,05$ dan nilai $t_{\text {hitung }}>\mathrm{t}_{\text {tabel }}$ dengan nilai 2,112 $>1,985$ dari hasil penelitian disimpulkan bahwa $\mathrm{H}_{2}$ diterima dan memiliki pengaruh yang signifikan, yang berarti faktor sosial berpengaruh positif dan signifikan terhadap keputusan pembelian pada produk olahan ikan laut (studi pada konsumen Sentra Ikan Bulak Kenjeran Surabaya).

Berdasarkan variabel faktor sosial indikator terdiri dari: keberadaan teman untuk memilih produk olahan ikan laut (OIL), keberadaan anggota keluarga untuk memilih 
produk olahan ikan laut (OIL), dan status sosial konsumen yang dilihat dari keberadaan lingkungan tempat tinggal mereka. Berikut merupakan pembahasan dari masing-masing indikator. Pertama keberadaan teman untuk memilih produk olahan ikan laut (OIL) bahwa konsumen mengetahui informasi Sentra Ikan Bulak menjual segala macam produk olahan ikan laut (OIL) berasal dari teman.

Kedua, keberadaan anggota keluarga dalam memilih produk olahan ikan laut (OIL), konsumen yang datang ke SIB memutuskan untuk melakukan pembelian karena adanya testimoni positif yang disampaikan kepada keluarga. Ketiga, peran dan status konsumen dalam memutuskan pembelian produk olahan ikan laut (OIL) di Sentra Ikan Bulak dapat dilihat dari keinginan konsumen melakukan pembelian muncul karena konsumen penasaran dengan informasi yang telah diberikan masyarakat di lingkungan tempat tinggal mereka seperti rasa ikan laut yang diolah dengan berbagai macam sehingga mereka tertarik untuk mencoba melakukan pembelian.

Penelitian ini sejalan dengan teori menurut Kotler \& Keller, (2012) kelompok acuan adalah semua kelompok yang mempunyai pengaruh langsung maupun tidak terhadap perilaku orang lain. Seperti kelompok dari keanggotaan (membership), kelompok sekunder yang cenderung lebih resmi. Keluarga adanya keluarga orientasi (orangtua dan saudara kandung) dan keluarga prokreai (pasangan dan anak-anak). Peran dan status yang dapat didefinisikan sebagai posisi seseorang dalam tiap kelompok dimana ia menjadi anggota. Penelitian ini memiliki hasil yang sama dengan penelitian Nawawi, (2016) yang menunjukan bahwa faktor sosial berpengaruh positif dan signifikan terhadap keputusan pembelian pada smartphone Blackberry.

\section{Pengaruh faktor personal terhadap keputusan pembelianpada produk olahan ikan laut (studi pada konsumen Sentra Ikan Bulak Kenjeran Surabaya)}

Berdasarkan hasil olah data penelitian ini, uji $\mathrm{t}$ (parsial) menunjukan bahwa besarnya pengaruh $\mathrm{X}_{3}$ terhadap $\mathrm{Y}$ adalah 0,002 $<\mathrm{a}=0,05$ dan nilai $t_{\text {hitung }}>t_{\text {tabel }}$ dengan nilai 3,167 $>1,985$, dapat disimpulkan bahwa $\mathrm{H}_{3}$ diterima dan memiliki pengaruh yang signifikan, yang berarti faktor personal berpengaruh positif dan signifikan terhadap keputusan pembelian pada produk olahan ikan laut (Studi pada Konsumen Sentra Ikan Bulak Kenjeran Surabaya).

Berdasarkan variabel faktor personal indikator dalam penelitian ini terdiri dari: usia, pekerjaan, keadaan ekonomi (penghasilan), gaya hidup, dan kepribadian. Berikut pembahasan dari masing-masing indikator. Pertama, usia dan siklus hidup konsumen dilihat dari hasil responden yang berkunjung di Sentra Ikan Bulak didominasi oleh usia 21-30 tahun, dan 31-40 tahun. Kedua, pekerjaan dilihat dari responden Sentra Ikan Bulak mayoritas responden yang berbelanja di SIB adalah yang bekerja sebagai karyawan. Ketiga, pendapat ekonomi (penghasilan) responden Sentra Ikan Bulak adalah kalangan pekerja yang sudah cukup untuk memenuhi kebuthan hidup.

Keempat, gaya hidup responden Sentra Ikan Bulak dipengaruhi dari pergeseran pola hidup masyarakat saat ini yang banyak dipengaruhi dengan perkembangan teknologi yang semakin pesat. Menurut (Furaiji et al., 2012) faktor personal menjadi gambaran pentingnya kepribadian berbeda setiap orang yang mempengaruhi perilaku pembeliannya. Hal ini karena masyarakat memiliki kesadaran menjalani hidup mereka yang berusaha untuk memenuhi kebutuhan dan keinginan mendapatkan produk dan layanan terbaik guna memuaskan kebutuhan dasar mereka sesuai dengan siklus kehidupan mulai pekerjaaan, situasi ekonomi, gaya hidup, dan kepribadian. Hasil penelitian ini bertentangan dengan temuan (Furaiji et al., 2012) yang menyatakan faktor personal tidak memiliki hubungan perilaku konsumen dengan keputusan pembelian.

\section{Pengaruh faktor psikologis terhadap keputusan pembelianpada produk olahan ikan laut (studi pada konsumen Sentra Ikan Bulak Kenjeran Surabaya)}

Berdasarkan hasil olah data penelitian ini, uji $t$ (parsial) menunjukan bahwa besarnya pengaruh $\mathrm{X}_{4}$ terhadap $\mathrm{Y}$ adalah $0,000<\mathrm{a}=0,05$ dan nilai $t_{\text {hitung }}>\mathrm{t}_{\text {tabel }}$ dengan nilai 4,016 $>1,985$, maka dapat disimpulkan bahwa $\mathrm{H}_{4}$ diterima dan memiliki pengaruh yang signifikan, yang berarti faktor Psikologis mempunyai pengaruh positif dan signifikan terhadap keputusan pembelian pada produk olahan ikan laut (Studi pada Konsumen Sentra Ikan Bulak Kenjeran Surabaya).

Berdasarkan variabel faktor psikologis indikator dalam penelitian ini terdiri dari: 
motivasi, persepsi, pembelajaran, dan sikap. Berikut pembahasan dari masing-masing indikator. Pertama, motivasi konsumen yang berkunjung ke Sentra Ikan Bulak karena di pengaruhi oleh banyaknya pilihan produk olahan ikan laut (OIL), sehingga menimbulkan daya tarik konsumen untuk melakukan pembelian.

Kedua, Persepsi konsumen yang menginterpretasikan perolehan informasi dari berbagai sumber, diantaranya: media online mengenai Sentra Ikan Bulak atau dari lingkungan sekitar. Ketiga, pembelajaran atau pengetahuan tentang produk olahan ikan laut (OIL). konsumen yang berkunjung di Sentra Ikan Bulak mengenai pengetahuan tentang produk olahan ikan laut (OIL) apa yang diinginkan dan sejauh mana manfaat produk yang ditawarkan. Keempat, Sikap konsumen Sentra Ikan Bulak yang mempunyai komitmen untuk melakukan pembelian. Komitmen didasari atas kepercayaan terhadap produk yang dibeli.

Hasil penelitian ini sejalan dengan temuan yang dilakukan oleh Yulianto et al., (2016) yang menjelaskan bahwa faktor psikologis adalah bagian motivasi yang akan menyebabkan timbulnya minat. Temuan penelitian ini menjelaskan bahwa faktor psikologis berpengaruh secara signifikan terhadap keputusan pembelian dimana kebanyakan konsumen mengalami jenis kebutuhan dan motif yang sama, namun cara menyatakan berbeda-beda.

Pengaruh faktor budaya, faktor sosial, faktor personal dan psikologis secara bersama-sama terhadap keputusan pembelianpada produk olahan ikan laut (Studi pada Konsumen Sentra Ikan Bulak Kenjeran Surabaya)

Faktor budaya, sosial, personal dan psikologis berpengaruh secara simultan (bersama-sama) terhadap keputusan pembelian produk olahan ikan laut (OIL) di Sentra Ikan Bulak. Bersumber dari data yang diolah menggunakan SPSS version 23 diperoleh nilai $f$ pada tabel anova adalah 8,669 ( $f_{\text {hitung }}$ ). Hasil $\mathrm{f}_{\text {tabel }}$ diperoleh sebesar 2,47 dengan signifikasi 0,000. karena $f_{\text {hitung }}>f_{\text {tabel }}(8,677>2,47)$ dengan nilai signifikansi 0,000 lebih kecil dari 0,05 $(0,000>0,05)$ maka $\mathrm{H}_{5}$ diterima. Sehingga dapat disimpulkan bahwa antara faktor budaya $\left(\mathrm{X}_{1}\right)$, faktor sosial $\left(\mathrm{X}_{2}\right)$, faktor personal $\left(\mathrm{X}_{3}\right)$ dan faktor psikologis $\left(\mathrm{X}_{4}\right)$ berpengaruh secara simultan terhadap keputusan pembelian produk olahan ikan laut (OIL) di Sentra Ikan Bulak Surabaya.

\section{SIMPULAN DAN SARAN}

\section{Simpulan}

Berdasarkan analisis data pembahasan mengenai faktor budaya, faktor sosial, faktor personal, dan faktor psikologis terhadap keputusan pembelian produk olahan ikan laut di Sentra Ikan Bulak Surabaya dapat diambil kesimpulan sebagai berikut:

1. Faktor budaya memiliki pengaruh yang positif dan signifikan secara parsial terhadap keputusan pembelian olahan Sentra Ikan Bulak Kenjeran (SIB).

2. Faktor sosial memiliki pengaruh yang positif dan signifikan secara parsial terhadap keputusan pembelian olahan Sentra Ikan Bulak Kenjeran (SIB).

3. Faktor personal memiliki pengaruh yang positif dan signifikan secara parsial terhadap keputusan pembelian olahan Sentra Ikan Bulak Kenjeran (SIB).

4. Faktor psikologi memiliki pengaruh yang positif dan signifikan secara parsial terhadap keputusan pembelian olahan Sentra Ikan Bulak Kenjeran (SIB).

5. Faktor budaya, faktor sosial, faktor personal dan faktor psikologis memiliki pengaruh yang positif dan signifikan secara simultan terhadap keputusan pembelian olahan Sentra Ikan Bulak Kenjeran (SIB).

\section{Saran}

Berdasarkan hasil kesimpulan tersebut, maka ada beberapa saran yang peneliti sampaikan sebagai berikut:

1. Terkait faktor budaya, bagi pelaku usaha sebaiknya lebih memperhatikan citra (pandangan yang baik) terhadap pelayanan dan menjaga mutu dengan kualitas yang lebih baik lagi dikarenakan banyak konsumen yang memutuskan pembelian dan sudah mempercayai produk olahan ikan laut di Sentra Ikan Bulak sejak awal membeli hingga saat ini sehingga tidak mengecewakan konsumen.

2. Terkait faktor sosial, bagi pelaku usaha sebaiknya penjual Sentra Ikan Bulak dapat meminta konsumen untuk merekemondasikan produk olahan ikan laut kepada teman atau keluarga mereka 
serta untuk pihak manajemen terkait juga dapat menggelar sosialisasi "Bulak Festival 2" kembali agar dapat menarik perhatian masyarakat terutama bagi warga Bulak untuk menempati stand yang disediakan di Sentra Ikan Bulak agar tidak dibiarkan kosong.

3. Terkait faktor personal bagi pelaku usaha agar dapat menyesuaikan perkembangan teknologi seperti menyediakan pembayaran melalui uang elektronik seperti menggunakan ovo, dana, shopeepay dan lainnya. Sehingga dapat menarik daya beli konsumen sesuai dengan perkembangan zaman.

4. Terkait faktor psikologis bagi pelaku usaha agar dapat menjaga citra ukm atau stand mereka dengan pilihan produk yang berbagai macam, berkualitas serta dengan harga yang terjangkau sehingga konsumen tertarik untuk memutuskan pembelian. Kepada pihak manajemen agar dapat memperhatikan juga lingkungan sekitar seperti, pengadaan meja yang baru, pengecatan tembok yang sudah pudar, terutama tempat pengasapan. Semua itu bertujuan untuk menarik daya beli konsumen agar lebih termotivasi untuk membeli produk olahan ikan laut di Sentra Ikan Bulak Surabaya.

5. Terkait keputusan pembelian bagi seluruh pihak baik untuk penjual maupun manajemen agar dapat mempromosikan produk olahan ikan laut agar lebih dikenal dan lebih dipercaya oleh konsumen seperti memanfaatkan website Sentra Ikan Bulak dengan melakukan update terbaru terkait produk yang dijual di Sentra Ikan Bulak.

\section{DAFTAR PUSTAKA}

Asriningputri, N., \& Handayeni, K. D. M. E. (2019). Strategi Pengembangan Industri Pengolahan Hasil Perikanan di Kecamatan Bulak Melalui Pendekatan Pengembangan Ekonomi Lokal (PEL). Jurnal Teknik ITS, 7(2), $\quad$ 5-9. https://doi.org/10.12962/j23373539.v7i2.3 3116

Badan Pusat Statistik Provinsi Jawa Timur. (2019). Produksi Perikanan Menurut Kabupaten/Kota dan Subsektor di Provinsi Jawa Timur (ton), 2016 dan 2017.

Djunaidah, I. S. (2017). Tingkat Konsumsi Ikan di Indonesia: Ironi di Negeri Bahari. Jurnal Penyuluhan Perikanan Dan Kelautan, 11(1), 12-24.

Fatihudin, D. (2015). Metode Penelitian untuk Ilmu Ekonomi, Manajemen dan Akuntansi. Zifatama Publisher.

Ferdinand, A. (2011). Metode Penelitian Manajemen Pedoman Penelitian untuk Penulisan Skripsi Tesis dan disertai Ilmu Manajemen. In Semarang: Universitas Diponegoro.

Furaiji, F., Łatuszyńska, M., \& Wawrzyniak, A. (2012). An empirical study of the factors influencing consumer behaviour in the electric appliances market. Contemporary Economics, 6(3), 76-86. https://doi.org/10.5709/ce.1897-9254.52

Ghozali, I. (2016). Aplikasi Analisis Multivariate dengan Program IBM SPSS 23 . Edisi 8. Cetakan ke-8. Semarang: Badan Penerbit Universitas Diponegoro. 2011.

Karunia Setyowati Suroto, K. S. S. (2013). Factors influencing consumer's purchase decision of formula milk in Malang City. IOSR Journal of Business and Management, 9(3), 95-99. https://doi.org/10.9790/487x-0939599

Kementerian Kelautan dan Perikanan Republik Indonesia. (2019). PRODUKTIVITAS PERIKANAN INDONESIA. In Kementerian Kelautan dan Perikanan Republik Indonesia. https://doi.org/10.1007/978-3-642-215018_59

Kessuvan, A., Parthanadee, P., \& Buddhakulsomsiri, J. (2015). The study of consumption behaviors and factors affecting decision to purchase fishery products of consumers in the North and Northeast of Thailand. 22(6), 2670-2678.

Kotler, P., \& Keller, K. L. (2012). Manajemen Pemasaran. Penerbit Erlangga.

Maro'ah, S. (2016). Pemasaran Produk Olahan Ikan Laut Ukm Kenjeran Surabaya Berbasis Marketing Mix Syariah. Jurnal Balance, XIII(2).

N Ramya, \& Ali, S. M. (2016). Factors Affecting Consumer Buying Behaviour. International Journal of Appl Ied Research, 2(10), 76-80. https://doi.org/10.21474/ijar01/8362

Nasermoadeli, A., Ling, K. C., \& Maghnati, F. (2013). Evaluating the Impacts of 
Customer Experience on Purchase Intention. International Journal of Business and Management, 8(6). https://doi.org/10.5539/ijbm.v8n6p128

Nawawi, M. T. (2016). Factors of Consumer Behavior That Affect Purchasing Decisions on Blackberry Smartphone. The Winners, 17(1), https://doi.org/10.21512/tw.v17i1.1810

Pemani, P., \& Massie, J. (2017). THE EFFECT OF PERSONAL FACTORS ON CONSUMER PURCHASE DECISION (Case Study: Everbest Shoes). Jurnal Riset Ekonomi, Manajemen, Bisnis Dan Akuntansi, 5(1), 68-77.

Qazzafi, S. (2019). CONSUMER BUYING DECISION PROCESS TOWARD PRODUCTS. International Journal of Scientific Research and Engineering Development, 2(5).

Rangkuti, F. (2009). Strategi Promosi yang Kreatif dan Analisis Kasus Integrated Marketing Communication. PT Gramedia Pustaka Utama.

Schiffman, L. G., \& Kanuk, L. L. (2010). Consumer Behavior 10th Edition. In Pearson Education.

Silalahi, U. (2012). Metode Penelitian Sosial. Refika Aditama.

Stankevich, A. (2017). Explaining the Consumer Decision-Making Process: Critical Literature Review. Journal of International Business Research and Marketing, 2(6), 714. https://doi.org/10.18775/jibrm.18498558.2015.26.3001

Supriadi, D., Kusuma, T. N. H. W., \& Gumilang, A. P. (2019). ANALISIS NILAI TUKAR PENGOLAHAN HASIL PERIKANAN PADA UNIT PENGOLAHAN IKAN SKALA KECIL DI KOTA CIREBON. Barakuda 45, 1(2), 57-71.

Swastha, B., \& Handoko, T. H. (2012). Manajemen pemasaran: Analisa perilaku konsumen. BPFE, Yogyakarta.

Tjiptono, F. (2014). Pemasaran Jasa (Prinsip, Penerapan, Penelitian). Andi.

Wahyudi, A., Kuwornu, J. K. M., Gunawan, E., Datta, A., \& Nguyen, L. T. (2019). Factors influencing the frequency of consumers' purchases of locally-produced rice in Indonesia: A Poisson regression analysis. Agriculture (Switzerland), 9(6). https://doi.org/10.3390/agriculture9060117
Yulianto, E., Fauzie, D., \& Sunarti. (2016). Pembelian ( Survei Pada Konsumen KFC Cabang Mall Olympic Garden Malang ). Jurnal Administrasi Bisnis (JAB), 40(1), 17. 